\title{
MINERALIZAÇÕES DE OURO DO TIPO OROGÊNICO EM ARCO MAGMÁTICO PALEOPROTEROZÓICO, BORDA OESTE DO CRATON SÃO FRANCISCO, REGIÕES DE SÃO DOMINGOS (GO) E CORRENTINA (BA)
}

\author{
CARLOS ALBERTO RENDÓN DÁVILA* \& RAUL MINAS KUYUMJIAN*
}

\begin{abstract}
OROGENIC-TYPE GOLD MINERALIZATIONS IN PALEOPROTEROZOIC MAGMATIC ARC, WESTERN BORDER OF THE SÃO FRANCISCO CRATON, SÃO DOMINGOS (GO) AND CORRENTINA (BA) REGIONS, BRAZIL. The metavolcanosedimentary sequences and associated plutonic rocks from the São Domingos area, State of Goiás, and Correntina area, State of Bahia, located at the border of the São Francisco Craton, were emplaced during the Paleoproterozoic in an oceanic, island-arc tectonic environment. The metassedimentary rocks from the sequences display different phases of deformation related to the Transamazônico Orogeny, reactivated during the Brasiliano Orogeny only in the Correntina region. The sequences studied and the oceanic island-arc type Almas-Dianópolis Terrane suggest a paleoproterozoic magmatic arc at the western border of the São Francisco Craton. The gold mineralizations are hosted by quartz veins which are fillings of Transamazonic fractures. In the São Domingos area, the quartz veins occur in phyllite and tonalite and are bordered by hydrothermal alteration zone, mainly kaolinization, while in the Correntina area, the veins crosscut tonalite and basic-ultrabasic rocks and are bordered by hydrothermal alteration zone enriched in biotite and carbonate. Gold generally ocurrs as millimetric grains and pyrite is the only sulphide present in the auriferous quartz veins. Fluid inclusion studies in vein quartz from São Domingos revealed the presence of aqueous and carbonic fluids, minimum fluid trapping temperature and pressure of about $300^{\circ} \mathrm{C}$ and $2 \mathrm{~kb}$, respectively, and low salinity, wich suggests a metamorphic origin for the fluid. Trace element composition of the hydrothermal alteration zones indicates that granitoids and pyrite-rich carbonaceous phyllite in the São Domingos area, and monzogranite and basic-ultrabasic rocks in the Correntina area, were the main sources of gold to the hydrothermal metamorphic fluids. The gold mineralizations of the São Domingos and Correntina areas and also those of the paleoproterozoic Almas-Dianópolis Terrane, indicate a very good potencial of the paleoproterozoic magmatic arc in the western border of the São Francisco Craton for orogenic lode-gold deposits.
\end{abstract}

Keywords: magmatic arc, Paleoproterozoic, geochemistry, fluid inclusions, orogenic gold deposits, São Domingos, Correntina.

Resumo As seqüências metavulcanossedimentares e rochas plutônicas associadas as janelas erosivas de São Domingos, (GO), e Correntina, (BA), localizadas na borda ocidental do Cráton São Francisco foram posicionadas em ambiente geotectônico de arco de ilha, evidenciado a partir de dados de litogeoquímica de riolito da seqüência e granitos associados, ambos de idade provavelmente paleoproterozóica. As rochas metassedimentares das seqüências mostram diferentes fases de deformação, geradas durante o Evento Transamazônico, com reativação no Evento Brasiliano somente na região de Correntina. Juntamente com as rochas do Terreno AlmasDianópolis, TO, formadas também em ambiente de arco de ilha no Paleoproterozóico, seqüências metavulcanossedimentares e rochas plutônicas de São Domingos e Correntina indicam a presença de um arco magmático paleoproterozóico na borda ocidental do Cráton São Francisco. As mineralizações de ouro em São Domingos e Correntina são hospedadas por veios de quartzo encaixados em fraturas originadas durante o Evento Transamazônico. Em São Domingos, os veios de quartzo, presentes em filito e tonalito, são bordejados por zonas de alteração hidrotermal, principalmente a argila, enquanto que em Correntina, os veios, presentes em tonalito e rochas básicas-ultrabásicas, são bordejados por zona rica em biotita e carbonato. O ouro ocorre na forma de grãos de até 3 mm de dimensão, em Correntina, e muito fino em São Domingos, evidenciado somente por meio de análise química. Pirita constitui o único sulfeto presente nos veios de quartzo auríferos. Dados obtidos em inclusões fluidas dos veios de quartzo revelam a presença de fluidos aquoso e carbônico, de baixa salinidade, temperatura $>300^{\circ} \mathrm{C}$, pressão de $>2 \mathrm{~kb}$, diagnosticando origem metamórfica para os mesmos. As concentrações de elementos traço nas rochas produtos de alteração hidrotermal indicam que, em São Domingos, granitóides e filito carbonoso rico em pirita constituíram fontes do ouro das mineralizações, enquanto que em Correntina monzogranito e rochas básicaultrabásicas. As ocorrências de ouro enfocadas, juntamente com aquelas do Terreno Almas-Dianópolis, TO, indicam excelente potencialidade do arco magmático paleoproterozóico da borda ocidental do Cráton São Francisco para depósitos do tipo orogenic lode-gold.

Palavras-chave: arco magmático, paleoproterozóico, geoquímica, inclusões fluidas, depósitos orogênicos de ouro, São Domingos, Correntina.

INTRODUÇ̃̃O A região de São Domingos localiza-se na borda ocidental do Cráton São Francisco, na região limítrofe entre os estados de Goiás e Bahia, a uma distância de 490 km de Brasília (Fig. 1). A Sequência metavulcanossedimentar São Domingos (SSD), plutônicas associadas e seu embasamento siálico constituem uma janela erosiva de aproximadamente $20 \mathrm{~km}$ segundo NS e $10 \mathrm{~km}$ de largura, cuja superfície aplainada é relacionada ao Ciclo
Velhas. A região de São Domingos fez parte do Projeto Brasília (Barbosa et al. 1969), o qual constou de mapeamento geológico na escala 1:250.000 de grande parte da região centro-oeste do então estado de Goiás. Em 1975, o mapeamento relativo à disciplina Trabalho Graduação de alunos do curso de Geologia da Universidade de Brasília foi desenvolvido na região de Galheiros (atual Divinópolis), $19 \mathrm{~km}$ a norte de São Domingos, e enfocou essen-

1 - Instituto de Geociências, Universidade de Brasília, 70910-900 Brasília, DF, rendon@unb.br, raulmk@unb.br 
Convenções

Fanerozóico

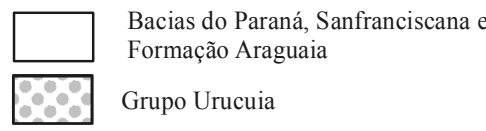

Neoproterozóico

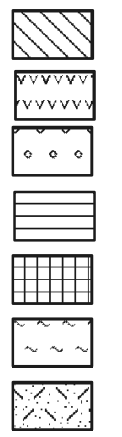

Ortognaisses

Seqüências vulcano-sedimentares

Formação Três Marias

Grupo Bambuí

Formação Ibiá

Grupo Araxá

Granulitos ácidos e básicos e ortognaisses

Meso/Neoproterozóico

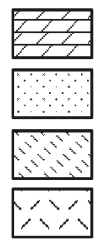

Grupo Vazante

Grupo Paranoá

Grupo Canastra

Grupo Estrondo

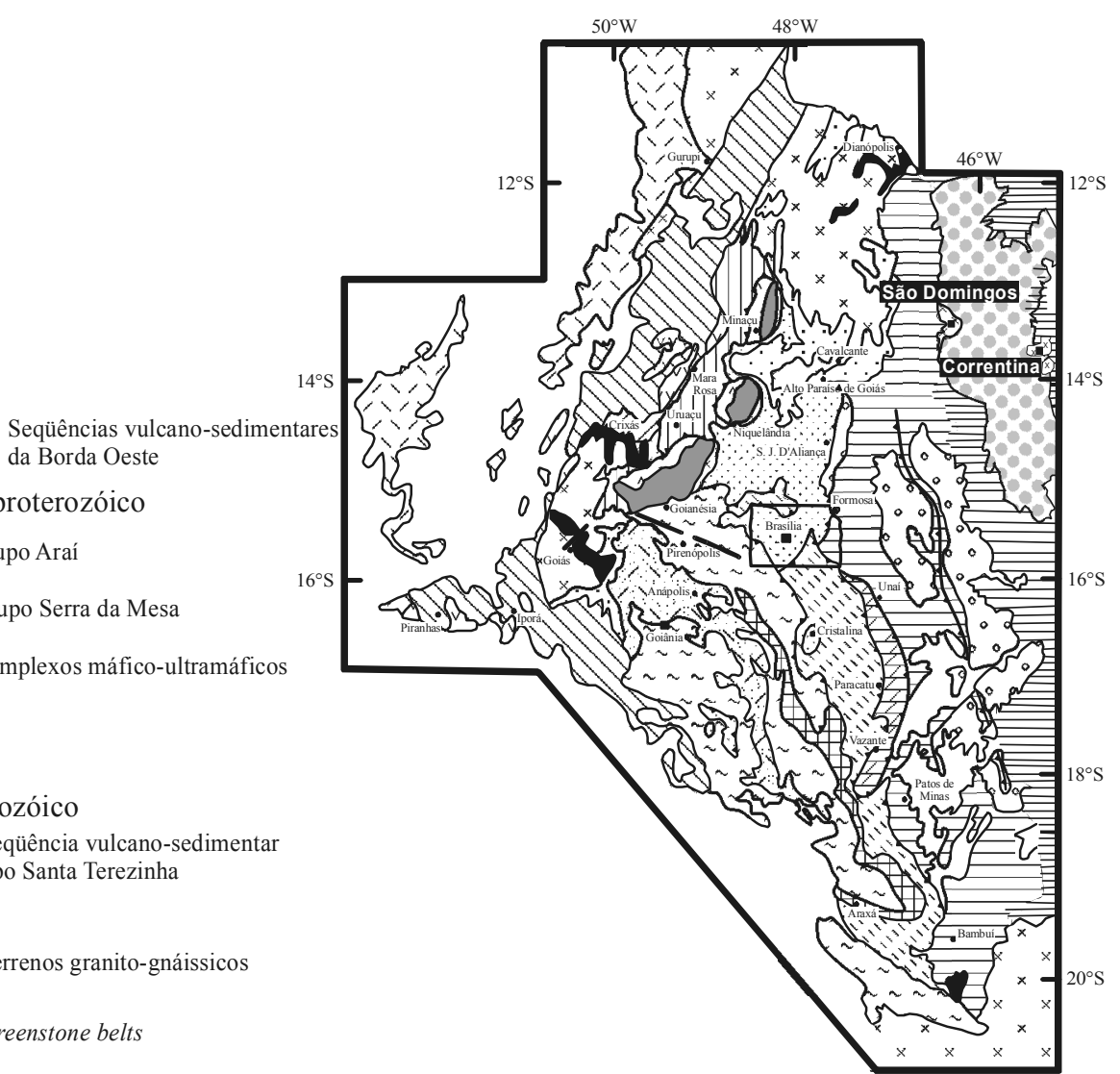

Figura 1 - Mapa geológico da Província Tocanstins e da parte oeste do Cráton São Francisco (Dardenne 2000, Dardenne \& Schobbenhaus 2001, Pimentel et al. 2000, 2001)

cialmente as rochas do Grupo Bambuí (Alvarenga \& Silva 1975). No inicio da década de 1980, geólogos da então Metais de Goiás S.A. desenvolveram mapeamento geológico e estudos de litogeoquímica no âmbito da SSD (Teixeira et al. 1982). Em 1986, alunos do curso de Geologia da Universidade de Brasília realizaram seu Trabalho Final de Graduação na região de São Domingos, o qual consistiu de mapeamento geológico no âmbito da seqüência metavulcanossedimentar e rochas intrusivas associadas, seu embasamento siálico e rochas sedimentares dos grupos Bambuí e Urucuia (Faria et al. 1986). Freitas-Silva \& Oliveira (1999) sugeriram que a sequência metavulcanossedimentar de São Domingos pertenceria a um ambiente de arco magmático formado no Paleoproterozóico e também, devido a similaridades dessa com as de Jacobina, Serrinha e Correntina, episódio de acreção e amalgamação crustal ao final do Paleoproterozóico, culminando com a individualização do Cráton São Francisco.

Na região de Correntina, localizada ao sudoeste do estado da Bahia, a uma distância de $520 \mathrm{~km}$ de Brasília, afloram rochas da seqüência de Correntina ( $\mathrm{SCO}$ ), com plutônicas associadas, e seu embasamento siálico, constituindo uma janela erosiva de aproximadamente $12 \mathrm{~km}$ na direção WE e $9 \mathrm{~km} \mathrm{NS}$, cuja superfície aplainada é relacionada ao Ciclo Velhas. Garimpos de ouro em aluviões foram explorados na região de Correntina desde meados do século XVIII. A Mineração Correntina Ltda. explorou o ouro primário entre 1975 e 1986, com uma produção de $70 \mathrm{~kg}$ de ouro (Azevedo et al. 1979). Geólogos da Companhia Baiana de Pesquisa Mineral executaram trabalhos de geologia e de prospecção na região de Correntina, evidenciando importantes anomalias geoquímicas de Au. O Projeto Correntina (Andrade et al. 1981) teve como objetivo estabelecer o potencial da área com relação a mineralizações de ouro e metais-base, enquanto que o Projeto Serra da Extrema (Andrade et al. 1988) desenvolveu trabalhos de levantamento geológico e de prospecção geoquímica em escala de detalhe no âmbito da mina São Rafael, evidenciando anomalias de maior constraste objetivando programa de sondagem.

O presente trabalho apresenta novos dados de geologia, litogeoquímica, geocronologia e mineralizações de ouro nas janelas erosivas de São Domingos e de Correntina, dados estes obtidos pelo autor principal em sua pesquisa em nível de Mestrado (Rendón 2002), recentemente concluída no Instituto de Geociências da Universidade de Brasília.

GEOLOGIA LOCAL São Domingos (SSD) A seqüência São Domingos (SSD) (Fig. 2) faz contato, a leste, com arenitos e conglomerados do Grupo Urucuia, sustentando a Serra Geral de Goiás, com maior desnível em torno de $300 \mathrm{~m}$ e cujo topo constitui uma superfíce aplainada resultante da ação do Ciclo Sul-Americano. A oeste, a seqüência faz contato com calcários, dolomitos e siltitos do Grupo Bambuí, cujo domínio é caracterizado por um relevo kárstico. As rochas intrusivas da área ocorrem no âmbito da SSD.

O embasamento siálico da SSD aflora imediatamente a norte e sul da mesma, compreendendo gnaisse granodiorítico, médio a 

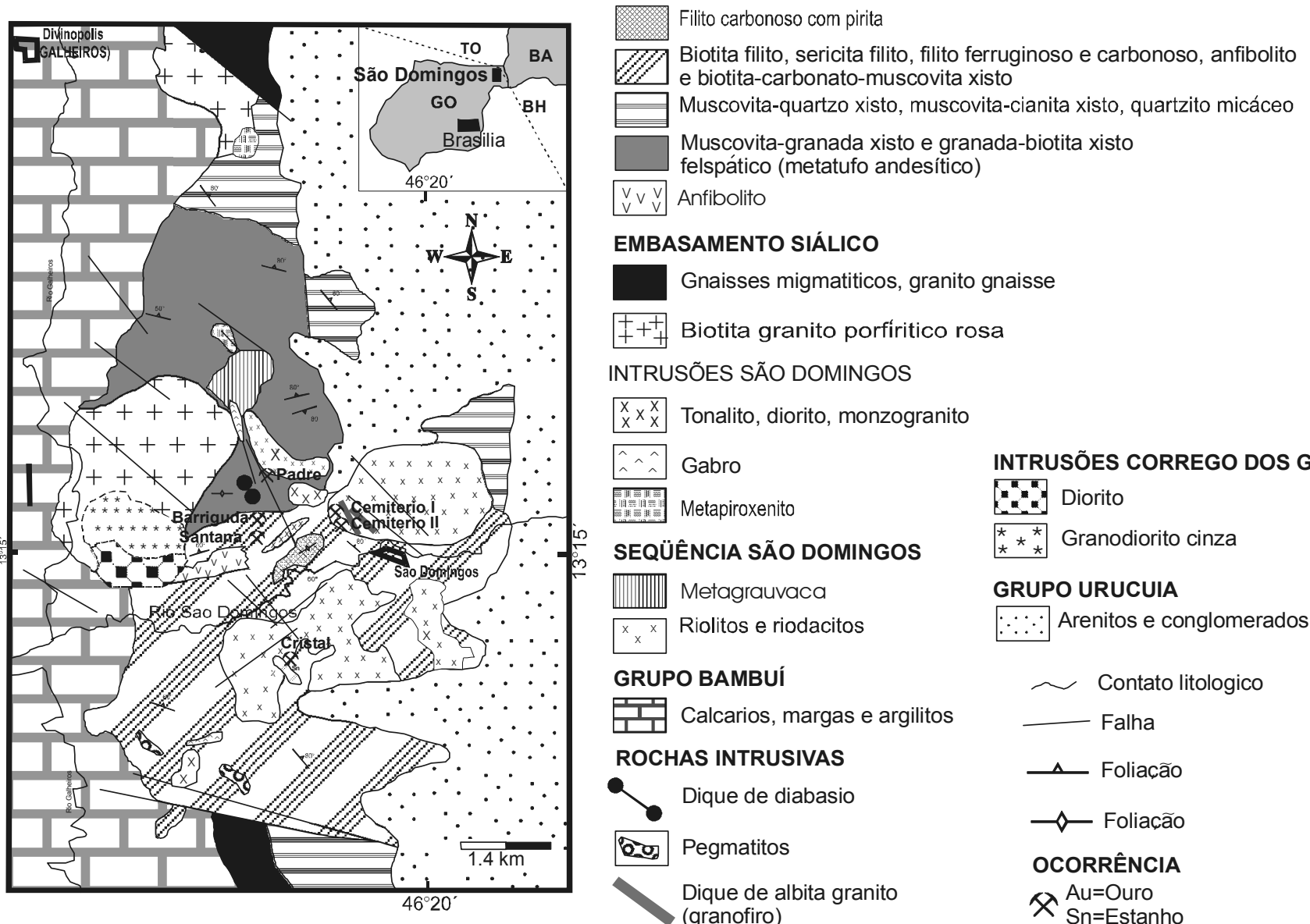

\section{EMBASAMENTO SIÁLICO}

Gnaisses migmatiticos, granito gnaisse

$\mp_{+}^{+}$Biotita granito porfíritico rosa

INTRUSÕES SÃO DOMINGOS

\section{\begin{tabular}{|lll}
\hline & $x$ & $x$ \\
$x$ & $x$
\end{tabular} Tonalito, diorito, monzogranito}

\begin{tabular}{|c|c|}
\hline$\hat{\hat{\wedge}} \hat{\wedge}$ & Gabro \\
\hline 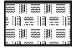 & Metapiroxenito \\
\hline
\end{tabular}

SEQÜENCIA SÃO DOMINGOS

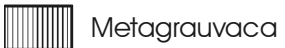

${ }^{x}{ }_{x}{ }^{x}$ Riolitos e riodacitos

GRUPO BAMBUÍ

Calcarios, margas e argilitos

ROCHAS INTRUSIVAS

Dique de diabasio
Pegmatitos
Dique de albita granito
(granofiro)

\section{INTRUSÕES CORREGO DOS GERAIS Diorito $\begin{array}{lll}* & * * \\ * & *\end{array}$ Granodiorito cinza}

GRUPO URUCUIA

$\because \because \therefore$ Arenitos e conglomerados

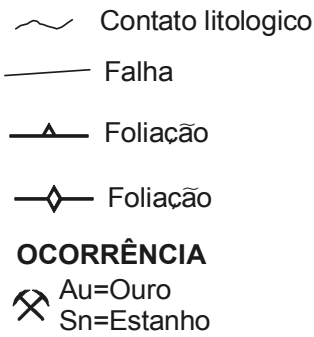

Figura 2 - Mapa geológico da região de São Domingos elaborado a partir de Teixeira et al. (1982), Faria et al. (1986), FreitasSilva (1997, inédito) e presente pesquisa.

grosso, localmente migmatítico, com intercalações centimétricas a métricas de lentes de metabásica e rocha cálcio-silicática. O contato entre o embasamento e a seqüência de São Domingos é tectônico, segundo falhas $\mathrm{N} 80^{\circ} \mathrm{W}$, a norte, e $\mathrm{N} 70^{\circ} \mathrm{W}$ a sul. As paragêneses de minerais metamóficos incluem granada+biotita no gnaisse, diopsídio+granada+hornblenda na calcissilicática e andesina+granada+hornblenda na metabásica, as quais, juntamente com a presença de migmatitos, diagnosticam fácies anfibolito alto.

$\mathrm{Na}$ seqüência São Domingos (SSD) dominam rochas metassedimentares, com intercalações de metavulcânicas ácida e básica. Na porção centro-sul da faixa, predomina sericita filito ferruginoso, avermelhado, com intercalações pouco espessas de clorita-filito esverdeado, filito carbonoso, localmente rico em pirita e, subordinadamente, quartzito e metachert. Já as metagrauvacas, contendo fragmentos de filito e metavulcânica ácida são mais freqüentes na porção central, e xistos (moscovita-granada-biotitaquartzo xisto e biotita-granada-quartzo xisto) na porção norte da mesma. Níveis pouco espessos ( 2 a $15 \mathrm{~m}$ ) de riolito a riodacito, transformados em moscovita xisto feldspático e intercalados em filito, têm ocorrência restrita na porção central da faixa. As rochas metavulcanicas mais conservadas têm fenocristais milimétricos de plagioclásio, parcialmente sausuritizado, e de quartzo imersos em matriz constituída de quartzo, plagioclásio, feldspato potássico, biotita parcialmente cloritizada, moscovita, magnetita e ilmenita.
Intercalados nos filitos ocorrem, também, níveis de 2 a $5 \mathrm{~m}$ de espessura de rocha basáltica, transformada em epidoto-actinolita xisto.

As paragêneses da SSD, isto é, plagioclásio sausuritizado, biotita, clorita. granada, moscovita, epidoto e actinolita, indicam condições de metamorfismo da fácies xisto verde. O empilhamento estratigráfico original da seqüência não foi reconhecido, uma vez que as unidades mostram-se desmembradas, descontínuas e submetidas a intensa deformação, a qual imprimiu uma foliação subvertical a vertical nas rochas. No entanto, a presença de fragmentos de filito e rocha metavulcânica ácida na metagrauvaca indica que esta foi depositada nos estágios finais de formação do pacote sedimentar da SSD.

Intrusões de tonalíto, monzogranito, granito, piroxenito e gabro atravessam a SSD. Os corpos de tonalito, com variações locais para diorito e monzogranito, localizam-se, principalmente, a norte e sudoeste de São Domingos (intrusão São Domingos), apresentando, em planta, forma aproximadamente circular com diâmetros em torno de $5 \mathrm{~km}$. Afloram na forma de elevações que se salientam na topografia da área, lajedos ou blocos métricos arredondados. O tonalito é cinza, com granulação média a grossa, textura equigranular, constituído de quartzo, plagioclásio saussuritizado, biotita, hornblenda e os minerais acessórios titanita, zircão e ilmenita. A presença de clorita e carbonato em microveios diagnostica a atuação de processos hidrotermais. As intrusões de 
granitos a oeste de São Domingos e leste de Divinópolis (intrusões Córrego dos Gerais) afloram na forma de extensos lajedos ou blocos métricos arredondados, localmente com metamorfismo de contato, evidenciado pela formação de xistos com andalusita. Três tipos faciológicos foram identificados, todos mostrando anisotropia incipiente: (a) biotita granito, tonalidade rósea, textura equigranular e granulação grossa, constituído de quartzo, microclínio, plagioclásio, parcialmente saussuritizado, biotita, parcialmente cloritizada, apatita e zircão como minerais acessórios ; (b) granito porfirítico cinza, granulação grossa, com fenocristais de feldspato potássico, contendo xenólitos centimétricos de rochas da seqüência; (c) gabro-diorito, constituído de quartzo, plagioclásio, biotita, microclínio e raros minerais opacos; albita-granito (granófiro) ocorre na forma de diques de direção $\mathrm{N} 80^{\circ} \mathrm{W}$ com até, $20 \mathrm{~cm}$ de espessura, e que cortam somente o tonalito. A principal intrusão básica-ultrabásica ocorre imediatamente a noroeste de São Domingos, constituindo um corpo de forma, aproximadamente, circular, de $1 \mathrm{~km}$ de diâmetro em superfície, sustentado por metapiroxenito (hornblenda+clorita+magnetita) e metagabro (hornblenda+plagioclásio+magnetita). Sondagens efetuadas pela empresa Metais de Goiás S.A. na mina Padre (ou Capote) interceptaram sill de metapiroxenito, com espessura variando de 5 a 10 metros, intercalado em granada filito.

Segundo Teixeira et al. (1982), a xistosidade na porção sul da SSD possui direção EW, com mergulhos altos e caimento ora para norte ora para sul. Na parte central da área, as atitudes, redeformadas pelas rochas plutonicas, mostram inflexão de NE para NW. Na porção norte, a xistosidade apresenta direção de $\mathrm{N} 30^{\circ}-40^{\circ} \mathrm{W}$ e mergulhos altos para NE. As principais falhas e fraturas possuem direções NNE, NE, NW e NWW-EW. Os dados estruturais obtidos no presente estudo permitem reconhecer três fases de deformação, mais evidentes nos filitos e xistos da SSD (Fig. 3). A primeira ( $\left.\mathrm{S}_{\mathrm{n}}\right)$, mais expressiva, é caracterizada pelo desenvolvimento de uma xistosidade de plano axial de dobras apertadas a isoclinais, de direção $\mathrm{N} 60^{\circ}-80^{\circ} \mathrm{W}$, mergulho vertical a subvertical, paralela às camadas $\left(\mathrm{S}_{0}\right)$, com intensa recristalização metamórfica envolvendo quartzo, mica e granada. A segunda fase de deformação $\left(\mathrm{S}_{\mathrm{n}+1}\right)$ imprimiu, localmente, foliação de crenulação de direção $\mathrm{N} 80^{\circ} \mathrm{W}$, com mergulho forte para NE, e mesodobras associadas, com eixos subverticais e, comumente, segregação de sílica na região de charneira sugerida pela presença de quartzo. A última fase de deformação $\left(\mathrm{S}_{\mathrm{n}+2}\right)$, reconhecida no filito, foi a menos intensa, tendo gerado uma clivagem de fratura de direção $\mathrm{N} 10^{\circ} \mathrm{W}$, com mergulho $10^{\circ}-20^{\circ} \mathrm{NE}$. A utilização de histograma polar eviden-

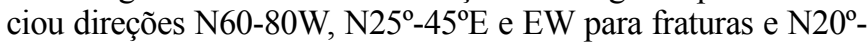
$45^{\circ} \mathrm{W}$ e $35 \mathrm{NE}$ para juntas, todas elas subverticais (Rendón 2002).

Filito e xisto verticalizados são cortados por veios de quartzo $\mathrm{N} 40^{\circ} \mathrm{E} ; 10^{\circ} \mathrm{NW}$, conseqüência de processo tardio $\left(\mathrm{S}_{\mathrm{n}+2}\right)$ de deformação rúptil, ao qual estão relacionadas as ocorrências de ouro na SSD e rochas plutônicas associadas. Os planos de fratura são preenchidos por quartzo que se apresentam, localmente, deformados, estriados e fraturados. As juntas são preenchidas por quartzo leitoso. Na região de São Domingos, as coberturas sedimentares pertencentes aos grupos Bambuí e Urucuia não são deformadas, e, portanto, as feições de deformação dúctil impressas na SSD e embasamento siálico resultaram de evento tectônico pré-Brasiliano, provavelmente Transamazônico (2,5-1,8 Ma).

Correntina Ageologia da janela erosiva de Correntina (Fig. 3), estudada em maior detalhe pelos projetos Correntina (Andrade et al. 1981) e Serra da Extrema (Andrade et al. 1988), é semelhante à da região de São Domingos (GO), compreendendo embasamento siálico, constituído de gnaisses e migmatitos; seqüência metavulcanossedimentar (SCO); stock de diorito, monzonito, tonalito, granodiorito e quartzosienito porfiríticos, pertencentes à Formação Correntina e intrusivo no embasamento síalico e seqüência metavulcanossedimentar; diques e sills de gabro e piroxenito, e veios de quartzo e pegmatito, intrusivos nas rochas do stock. A SCO faz contato, a leste, com calcáreos, dolomitos e siltitos do Grupo Bambuí, cujo domínio é caracterizado por relevo kárstico e, a oeste, com arenitos e conglomerados do Grupo Urucuia. As intrusivas presentes nesta área, ou sejam, tonalitos, monzodioritos, granitos e diques de rochas máficas são frequentes no âmbito da SCO. O embasamento sialico aflora a leste e oeste da SCO, sendo constituído de gnaisses e migmatitos de composição granodiorítica. A SCO, referida como Formação Extrema no Projeto Correntina (Andrade et al. 1988), é composta de filito, xisto e quartzito, intensamente deformados e submetidos a metamorfismo de fácies xisto verde. Tais rochas supracrustais ocorrem numa faixa de $6 \mathrm{~km}$ de comprimento e, no máximo, $1 \mathrm{~km}$ de largura, na direção NE-SW. O quartzito é branco ou amarelo, granulação muito fina, constituído de grãos equigranulares, bem selecionados. Lentes de metachert ocorrem intercalados nos filitos. A foliação predominante no xisto e filito tem atitude $\mathrm{N} 15^{\circ}-25^{\circ} \mathrm{E}$, $40^{\circ}-60^{\circ} \mathrm{NW}$. O xisto e filito, ambos quartzosos, são de tonalidade avermelhada, constituídos de finas palhetas de moscovita, clorita, minerais de argila e quartzo.

Os stocks e diques, incluídos na Formação Correntina, apresentam grandes variações composicionais, ou seja, monzonito, diorito, tonalito, granodiorito e granito. O monzodiorito e quartzo monzonito são rochas cinza-esverdeadas, de granulação grossa, pouco orientadas, constituídas de plagioclásio, minerais máficos (piroxênio, anfibólio e biotita) e feldspato potássico, com pouco quartzo. Tonalito e granito apresentam tonalidade cinza, são equigranulares, de granulação grossa, aflorantes na parte sul da cidade de Correntina. As rochas intrusivas máfica-ultramáficas constituem diques encaixados nas plutônicas, gnaisses e migmatitos, sendo que o principal corpo aflorante localiza-se a 1,5 km a sul de Correntina, na mina São Rafael (Fig. 3). Tais rochas, predominantemente metapiroxenito, apresentam cor verde a ama-

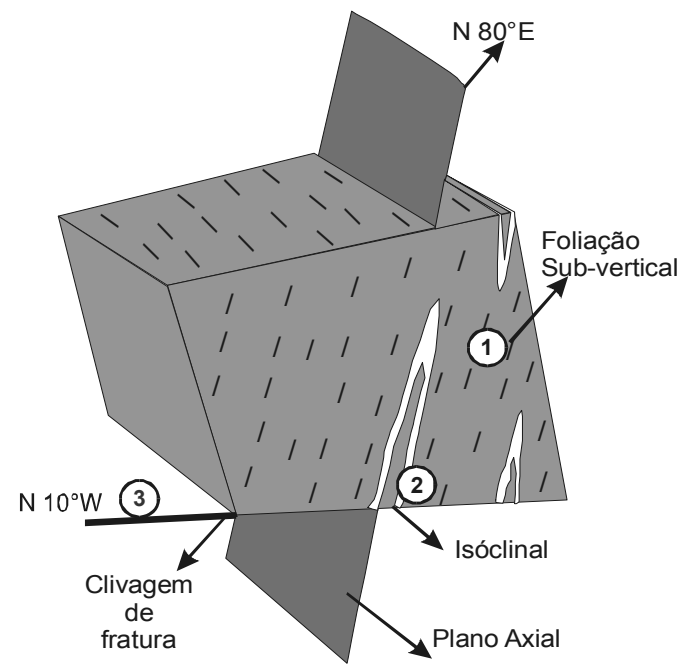

Figura 3 - Bloco esquemático das três fases de deformação no domínio dúctil presentes na SSD (Rendón 2002). 
relada, granulação fina e xistosidade, sendo constituídas de tremolita-actinolita, epidoto e clorita.

As rochas da área mostram, pelo menos, duas fases de deformação, uma compressiva e outra distensiva. A primeira, mais antiga e anterior à deposição do Grupo Bambuí, originou zonas de cisalhamento que controlam as ocorrências de ouro na região de Correntina. A segunda gerou estruturas do tipo blocos de falha, com falhamentos de direção EW e NNE-SSW, presentes no âmbito das rochas da $\mathrm{SCO}$ e do Grupo Bambuí.

\section{LITOGEOQUÍMICA E AMBIENTE GEOTECTÔNICO Segun-}

do Teixeira et al. (1982), os metabasaltos da SSD são toleíticos e as rochas metavulcânicas ácidas, calcio-alcalinas, e sugerem, para as mesmas, ambiente de formação do tipo rifte intracontinental. Para evidenciar o ambiente geotectônico de posicionamento da SSD e das rochas plutônicas associadas, considerou-se, no presente trabalho, a assinatura química de elementos traço das intrusivas granitóides, ou seja, tonalito, granito, granófiro, não deformados ou alterados, e de metavulcânicas ácidas. As análises químicas para elementos maiores foram efetuadas por espectrômetro de emissão atômica com plasma acoplado indutivo (ICP-AES), exceto sódio e potássio, determinados por espectrometria de emissão de chama, no Laboratório de Geoquímica do Instituto de Geociências da Universidade de Brasília, sendo que para a dissolução das amostras foi utilizado metaborato de lítio (Tabela 1). Os elementos traço foram dosados por ICP-MS no laboratório ACME Analytical Laboratories, do Canadá, tendo-se utilizado metaborato de lítio e água régia para a dissolução das amostras. Os fatores de normalização a granito de cadeia meso-oceânica (ORG) são os indicados por Pearce et al. (1984). Segundo Rendón (2002) os diagramas discriminantes utilizados, álcalis x sílica de La Roche et al. (1980), classificam as rochas plutônicas de São Domingos como monzogranito, sienogranito, granodiorito, tonalito, diorito, quartzo monzonito e, em Correntina, como monzogranito, sienogranito, granodiorito, monzodiorito e sienogabro; no diagrama de Maniar \& Picoli (1989), os granitóides são, predominantemente, metaluminosos e no digrama AFM, de Irvine \& Baragar (1971), é evidenciada afinidade calcio-alcalina. No diagrama $\mathrm{Rb} /(\mathrm{Y}+\mathrm{Nb})$ de
Pearce (1996), tonalito e granófiro posicionam-se no campo de granitos de arco vulcânico, enquanto que os granitos, na transição entre arco vulcânico, sin- e pós-colisionais (Fig. 5). Quando normalizados a ORG (granito de cadeia mesoceânica), evidenciam-se dois padrões de distribuição contrastantes: um padrão, inclui o monzogranito (amostra CR-15), quartzomonzonito, sienogranito, sienogabro e o sienito de Correntina, é fortemente inclinado, com acentuado enriquecimento em elementos litófilos e anomalias negativas de $\mathrm{Nb}$ e $\mathrm{Ba}$, e positivas de $\mathrm{Sm}$, semelhante aos padrões indicados por Pearce et al. (1984) para granito sincolisional de arco vulcânico (Fig. 6a). Outro padrão, correspondente a tonalito (amostra CR-01) e granófiro, apresenta inclinação menos acentuada, menor enriquecimento em elementos litófilos e anomalias negativas em $\mathrm{Nb}$ e Th, também característico de ambientes de arco vulcânico e de sin-colisão (Fig. 6b). O padrão de distribuição da metavulcânica ácida (CR-71) é semelhante aos das rochas granitóides, com acentuado enriquecimento em elementos litófilos (Fig. 6a).

GEOCRONOLOGIA O único dado geocronológico publicado até o presente para as rochas da região de São Domingos, ou seja, $2,042 \pm 0143 \mathrm{Ga}$, foi obtido pelo método K-Ar em anfibólio de metadiabásio (Hasui \& Almeida 1970). O migmatito do embasamento e os granitóides intrusivos na SCO foram datados por Mascarenhas \& Garcia (1989) e Cordani et al. (1979) tendo-se obtido isócoras de $\mathrm{Rb} / \mathrm{Sr}$ com idade aproximada de 2,0 Ga, enquanto que Sato (1998) obteve idade modelo de $\mathrm{Sm}-\mathrm{Nd}\left(\mathrm{T}_{\mathrm{DM}}\right)$ da ordem de 2,4 e 2,1 Ga.

$\mathrm{Na}$ presente pesquisa foram efetuadas determinações isotópicas $\mathrm{U}-\mathrm{Pb}$ em zircões das rochas metavulcânicas ácidas da SSD porém, não se obteve, até o presente, nenhum dado conclusivo sobre a idade de deposição da seqüência. Determinações adicionais de $\mathrm{U}-\mathrm{Pb}$ em zircões da metavulcânica ácida e de plutônicas estão em andamento. São apresentados resultados de análises isotópicas de $\mathrm{Sm}-\mathrm{Nd}$, efetuadas no Laboratório de Geocronologia da Universidade de Brasília. A dissolução das amostras foi efetuada em cápsula de Teflon Savillex, ou utilizando-se bombas de Teflon do tipo Parr, segundo metodologia sugerida por

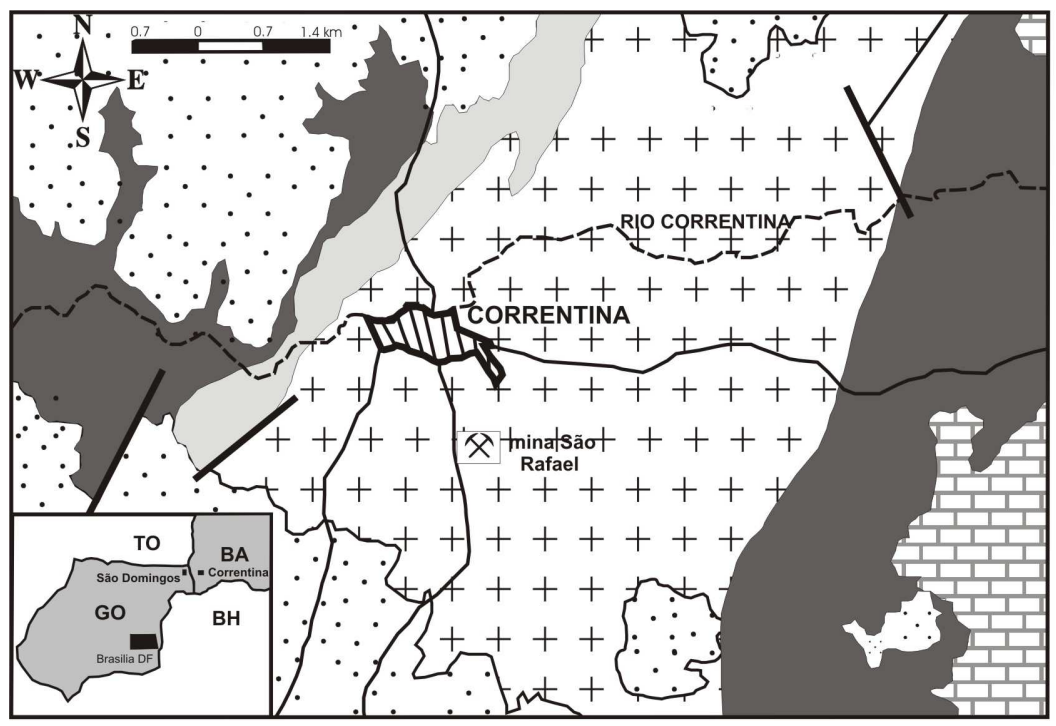

FORMAÇÃO EXTREMA

MICAXISTOS E FILITOS, XISTOS COM LENTE

EMBASAMENTO SIÁLICO

GNAISSES GRANITICOS

UPo Bambui

CALCARIOSE DOLOMITOS, LENTES

DEAC̄o CORRENTINA

FONZONITOS DIORITOS TONALITOS GRANODIORITOS E SIENITOS

GRUPO URUCUIA

ARENITOS FINOS, LENTES DE ARGILITO

$x$ MINA $ح$ ESTRADA

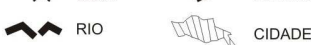

Figura 4 - Mapa geológico da região de Correntina (Andrade et al. 1981, Inda 1978, Moraes Filho 1997).). 
Mineralizações de ouro do tipo orogênico em arco magmático paleoproterozóico, borda oeste do Craton São Francisco, regiões de São Domingos (GO) e Correntina (BA).

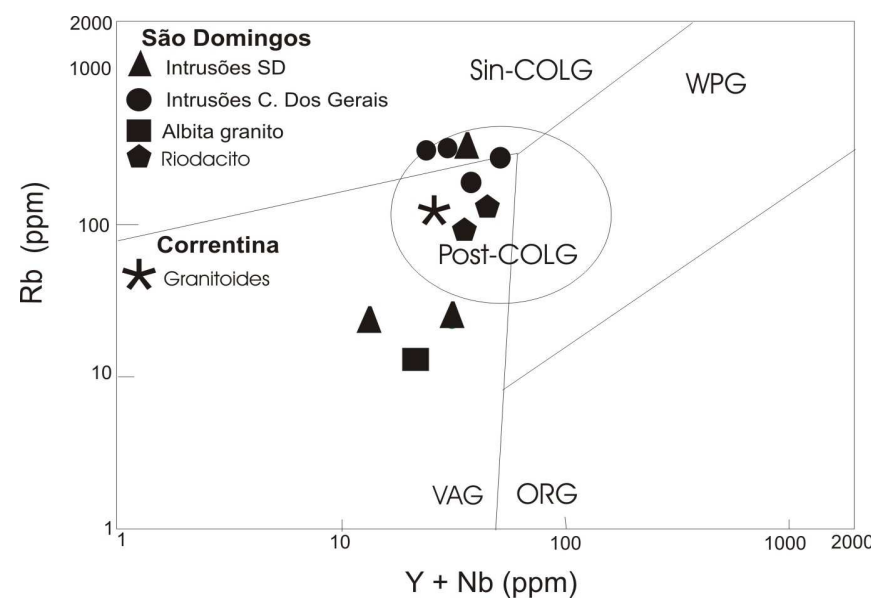

Figura 5 - Diagrama discriminante de ambiente geotectônico (Pearce et al. 1996) para rochas das seqüencias de São Domingos e Correntina.

Gioia \& Pimentel (2002). Para a extração de Sm e Nd foi aplicada a técnica de Richard et al. (1976), ou seja, separação dos elementos terras raras utilizando-se colunas de troca catiônica (coluna primária) e, em seguida, colunas contendo HDEHP - ácido di-2-etil-hexil fosfórico (coluna secundária) impregnada em pó de Teflon. As análises isotópicas de $\mathrm{Sm}-\mathrm{Nd}$, em modo estático, utilizando-se arranjo de filamento duplo, foram efetuadas por meio de espectrômetro de massa Finningan MAT 262, dotados de 7 coletores tipo "Faraday Cup". A razão ${ }^{143} \mathrm{Nd} /{ }^{144} \mathrm{Nd}$ foi normalizada para ${ }^{146} \mathrm{Nd} /{ }^{144} \mathrm{Nd}=0.07219$, e a constante de decaimento, $6.54 \times 10^{-12} / \mathrm{a}$. A precisão externa da razão ${ }^{143} \mathrm{Nd} /{ }^{144} \mathrm{Nd}$ variou de $0.0006 \%-0.0016 \%$ e o erro analítico da razão ${ }^{147} \mathrm{Sm} /{ }^{144} \mathrm{Nd} \leq 0.19 \%$.

As análises isotópicas de $\mathrm{Sm}-\mathrm{Nd}$ foram efetuadas em metagrauvaca, filito e metavulcânica ácida da SSD, objetivando identificar as fontes dos protolitos, e em tonalito e granito porfirítico, intrusivos nessas rochas metassedimentares, no intuito de se obter a idade modelo e a origem do magma que os geraram, e em uma amostra de granito gnáissico do embasamento siálico. Os resultados obtidos para as rochas metassedimentares revelam valores de ${ }^{147} \mathrm{Sm} /{ }^{144} \mathrm{Nd}$ em torno de 0.11 , idades modelo da maioria das amostras variando de 2,3 Ga a 2,6 Ga., e valores negativos de $\varepsilon_{\mathrm{Nd}}$, indicativo de derivação crustal. Os valores ${ }^{147} \mathrm{Sm} /{ }^{144} \mathrm{Nd}$ da rocha metavulcânica ácida variam de 0,07 a 0,17, semelhante às demais rochas analisadas, e possuem idades modelo de 2,2 Ga a 2,7 Ga. Os valores ${ }^{147} \mathrm{Sm} /{ }^{144} \mathrm{Nd}$ obtidos para tonalito, granito porfirítico, granófiro e granito gnáissico são, predominantemente, da ordem de 0,1 , semelhante às rochas metassedimentares. As rochas plutônicas possuem idades modelo similares, sendo as mais elevadas em torno de 2,5 Ga. Os resultados obtidos indicam derivação a partir de fonte crustal. A idade da fonte que gerou o granitognaisse do embasamento, a SSD e plutônicas associadas, é de $2,5 \pm 10 \mathrm{Ga}$ (Fig. 7) e, portanto, considerando a idade K-Ar de 2,4 Ga em anfibólio de metadiabásio intrusivo na SSD, evidencia-se idade paleoproterozóica para as rochas supracrustais e plutônicas da janela erosiva de São Domingos. Considerando-se os dados geocronológicos obtidos na região de Correntina, acima indicados, conclui-se que a SCO e rochas plutônicas associadas tenham se posicionado também durante o Paleoproterozóico.

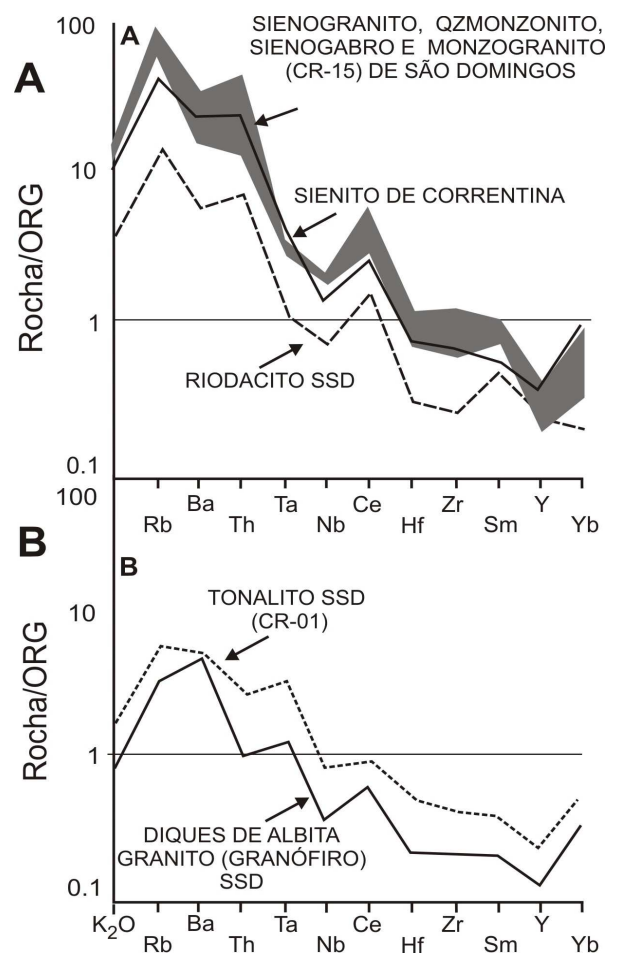

Figura 6 - Diagramas multielementares (Pearce 1996) para discriminação de ambiente geotectônico dos granitóides de São Domingos e Correntina

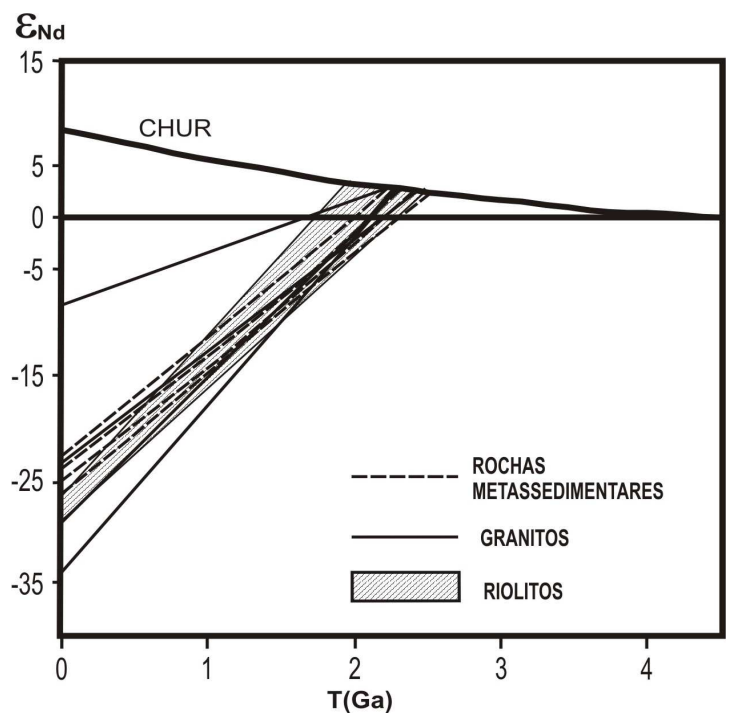

Figura 7 - Diagrama $\mathcal{E}_{N d}$ X Tempo para rochas da seqüência metavulcanossedimentar de São Domingos e rochas plutônicas associadas.

MINERALIZAÇÔES São Domingos ASSD hospeda ocorrências de ouro e de cassiterita, exploradas pelos bandeirantes no século XVIII e por meio de atividade garimpeira na década dos 1980. Em 1976, a Metais de Goiás S.A. desenvolveu programa de 
Tabela 1 - Resultado das análises químicas de rochas das seqüências de São Domingos e Correntina

\begin{tabular}{|c|c|c|c|c|c|c|c|c|}
\hline \multirow{3}{*}{$\begin{array}{c}\text { Area } \\
\text { Suit } \\
\text { Amostra } \\
\end{array}$} & \multicolumn{7}{|c|}{ SSD } & \multirow{3}{*}{$\begin{array}{c}\text { SCO } \\
\text { Correntina } \\
\text { CR-216 }\end{array}$} \\
\hline & \multicolumn{3}{|c|}{ Intrusões SD } & \multicolumn{2}{|c|}{ C. dos Gerais } & dique & Vulcânica & \\
\hline & \begin{tabular}{|c|} 
CR-01 \\
\end{tabular} & \begin{tabular}{|l|} 
CR-15 \\
\end{tabular} & \begin{tabular}{|l|l} 
CR-14 \\
\end{tabular} & \begin{tabular}{|c|} 
CR-12 \\
\end{tabular} & \begin{tabular}{|c|} 
CR-44 \\
\end{tabular} & CR-631 & CR-71 & \\
\hline Rocha & \begin{tabular}{|l|l} 
tonalito \\
\end{tabular} & monzogranito & sienogranito & qzmonzonito & sienogabro & granofiro & riodacito & sinogabro \\
\hline $\mathrm{Si} \mathbf{O 2}$ & 60,300 & 67,600 & 69,700 & 64,900 & 69,200 & 74,100 & 56,000 & 68,500 \\
\hline Ti O2 & 0,516 & 0,543 & 0,304 & 0,442 & 0,310 & 0,815 & 0,677 & 0,378 \\
\hline Al2 O3 & 15,870 & 15,140 & 15,080 & 16,710 & 15,860 & 13,530 & 24,600 & 14,890 \\
\hline Fe2 $\mathrm{O} 3$ & 6,200 & 2,879 & 1,878 & 3,128 & 2,590 & 2,130 & 6,570 & 3,131 \\
\hline Mn O & 0,077 & 0,057 & 0,019 & 0,055 & 0,043 & 0,027 & 0,491 & 0,037 \\
\hline Mg O & 4,170 & 0,636 & 0,446 & 0,664 & 0,665 & 0,816 & 1,706 & 0,929 \\
\hline Ca O & 6,240 & 1,689 & 0,994 & 1,888 & 1,169 & 2,408 & 0,707 & 2,065 \\
\hline $\mathrm{Na} 2 \mathrm{O}$ & 4,269 & 4,124 & 4,051 & 4,342 & 4,269 & 5,396 & 1,508 & 4,487 \\
\hline K2 O & 0,765 & 4,647 & 5,075 & 5,561 & 5,732 & 0,365 & 3,277 & 4,133 \\
\hline P2 O5 & 0,400 & 0,270 & 0,190 & 0,260 & 0,240 & 0,150 & 0,110 & 0,250 \\
\hline PF & 1,206 & 1,728 & 1,855 & 1,790 & 0,902 & 0,080 & 4,588 & 0,771 \\
\hline total & 100,014 & 99,313 & 99,593 & 99,738 & 100,980 & 99,816 & 100,234 & $\mathbf{9 9 , 5 7 1}$ \\
\hline $\mathbf{V}$ & 82,000 & 15,000 & 13,000 & 15,000 & 13,000 & 52,000 & 87,000 & 20,000 \\
\hline Nb & 3,500 & 19,700 & 17,800 & 16,800 & 18,400 & 7,700 & 13,200 & 10,300 \\
\hline $\mathrm{Sr}$ & 509,100 & 148,000 & 131,100 & 297,200 & 186,900 & 351,100 & 122,100 & 247,600 \\
\hline $\mathbf{Y}$ & 10,100 & 13,800 & 13,400 & 19,400 & 29,100 & 15,500 & 26,500 & 18,700 \\
\hline $\mathbf{Z r}$ & 78,300 & 343,000 & 190,200 & 360,000 & 212,200 & 137,900 & 133,000 & 172,500 \\
\hline $\mathbf{C u}$ & 21,090 & 4,063 & 2,070 & 23,740 & 13,890 & 93,000 & 35,000 & 13,680 \\
\hline $\mathrm{Be}$ & 0,966 & 5,130 & 3,476 & 2,802 & 2,813 & 1,236 & 3,590 & 2,062 \\
\hline $\mathrm{Cr}$ & 150,300 & 7,390 & 0,319 & 5,270 & 4,789 & 2,366 & 101,400 & 11,390 \\
\hline $\mathbf{B a}$ & 237,000 & 838,200 & 684,600 & 1595,700 & 940,500 & 221,500 & 667,900 & 924,900 \\
\hline Cs & 2,000 & 11,700 & 7,200 & 6,600 & 5,000 & 1,100 & 14,800 & 4,800 \\
\hline Ga & 17,100 & 23,000 & 22,600 & 22,600 & 20,700 & 16,100 & 31,400 & 18,000 \\
\hline Hf & 2,200 & 9,900 & 6,400 & 9,800 & 7,000 & 4,400 & 4,600 & 5,200 \\
\hline $\mathbf{R b}$ & 21,600 & 282,600 & 289,800 & 224,400 & 277,700 & 11,800 & 162,100 & 132,200 \\
\hline Sn & 1,000 & 4,000 & 3,000 & 4,000 & 4,000 & 1,000 & 6,000 & 2,000 \\
\hline Ta & 0,900 & 2,400 & 1,700 & 1,800 & 2,300 & 2,000 & 1,400 & 2,200 \\
\hline Th & 0,800 & 30,000 & 25,100 & 17,100 & 10,800 & 2,000 & 14,500 & 13,900 \\
\hline $\mathbf{U}$ & 0,300 & 4,100 & 2,900 & 2,900 & 1,600 & 0,900 & 4,600 & 3,800 \\
\hline La & 9,700 & 88,700 & 100,800 & 60,600 & 63,200 & 14,700 & 58,400 & 42,600 \\
\hline $\mathrm{Ce}$ & 20,700 & 161,300 & 169,100 & 112,700 & 113,600 & 30,000 & 114,300 & 69,800 \\
\hline Pr & 2,210 & 15,000 & 17,000 & 11,000 & 11,400 & 3,310 & 11,530 & 6,550 \\
\hline Nd & 10,100 & 55,800 & 63,100 & 43,500 & 44,000 & 15,100 & 43,800 & 25,400 \\
\hline Sm & 2,000 & 8,300 & 8,800 & 6,500 & 7,400 & 3,400 & 7,200 & 3,700 \\
\hline Eu & 0,680 & 0,690 & 0,570 & 1,240 & 0,610 & 0,960 & 1,810 & 0,570 \\
\hline Gd & 1,970 & 4,200 & 4,210 & 4,270 & 5,430 & 2,710 & 6,880 & 2,850 \\
\hline $\mathbf{T b}$ & 0,300 & 0,500 & 0,590 & 0,590 & 0,840 & 0,430 & 0,910 & 0,480 \\
\hline Dy & 1,490 & 2,280 & 2,380 & 3,120 & 4,130 & 2,270 & 4,150 & 2,650 \\
\hline Но & 0,380 & 0,370 & 0,360 & 0,610 & 0,900 & 0,510 & 0,840 & 0,590 \\
\hline Er & 0,930 & 0,830 & 0,860 & 1,680 & 2,550 & 1,460 & 2,500 & 1,630 \\
\hline Tm & 0,130 & 0,130 & 0,110 & 0,260 & 0,360 & 0,210 & 0,430 & 0,250 \\
\hline $\mathbf{Y b}$ & 0,920 & 0,840 & 0,860 & 1,890 & 2,460 & 1,450 & 2,480 & 1,760 \\
\hline Lu & 0,140 & 0,110 & 0,110 & 0,260 & 0,380 & 0,190 & 0,370 & 0,270 \\
\hline
\end{tabular}

exploração mineral para ouro no âmbito da seqüência, incluindo prospecção geoquímica na ocorrência Cemitério I, e sondagens na ocorrência do Capote, não tendo obtido concentrações de ouro que justificassem a continuidade das atividades exploratórias. Até o presente, nenhum estudo geológico mais aprofundado foi efetuado sobre as ocorrências de ouro e cassiterita.

OURO Segundo Rendón (2002) as principais ocorrências de ouro na SSD são as denominadas de Cemitério I, Cemitério II, Padre (ou Capote), Barriguda e Santana, localizadas próximas uma das outras, imediatamente a W-NW da cidade de São Domingos (Fig. 2). A ocorrência Cemitério I compreende veios de quartzo de, aproximadamente $1 \mathrm{~m}$ de espessura, de direção N20 $0^{\circ}-30^{\circ} \mathrm{E} / \mathrm{sub}-$ vertical. Localiza-se no tonalito, próximo do contato com granada filito da SSD, estando os veios bordejados por uma zona de alteração avermelhada de no máximo $80 \mathrm{~cm}$ de espessura, e mais externamente por uma zona esbranquiçada, métrica, onde predominam caolinita, quartzo e illita.

A ocorrência Cemitério II consiste de veios de quartzo em granada filito, muito próxima do contato com o tonalito de São Domingos. Os veios são pouco espessos (3 a $30 \mathrm{~cm}$ ), de direção $\mathrm{N} 30-40 \mathrm{~W} / 35 \mathrm{NE}$ ou sub-vertical, localmente mais espessos (1 metro), de direção $\mathrm{N} 45^{\circ}-55^{\circ} \mathrm{E} /$ sub-vertical e bordejados por zonas de alteração semelhantes às da ocorrência Cemitério I, porém mais estreitas, principalmente a zona avermelhada. A ocorrência Padre ou Capote consiste de veios de quartzo direcionados $\mathrm{EW} / 65^{\circ} \mathrm{S}$ e $\mathrm{N} 10^{\circ} \mathrm{W}$, sub-verticais, em metavulcânica ácida (riolito), a qual, em testemunhos de sondagem realizados pela Metais de Goiás S.A., apresentam de 2 a $20 \mathrm{~m}$ de espessura, intercalados em granada filito da SSD. O riolito apresenta-se milonitizado e submetido a alteração hidrotermal, a qual deu origem a vênulas e veios de quartzo, com espessura de, no máximo $5 \mathrm{~cm}$, e promoveu sericitização, carbonatização e cloritização. Pirita lamelar ocorre em fraturas no riolito. No contato com o riolito, o granada filito foi submetido a cloritização. Análises químicas, efetuadas pela Metais de Goiás S.A. em testemunhos de sondagens, revelam concentrações de ouro da ordem de 0,84 a 14,36 ppm, em veios de quartzo no riolito, e de 1,07 a 1,63 ppm em veios de quartzo no granada filito. Resultados analíticos obtidos no presente trabalho indicam concentrações de $\mathrm{Au}$ da ordem de $<0,10$ a 2,5 ppm, com maior freqüência entre 0,11 e 0,18 ppm e um valor de 52,8 ppm em metavulcânica acida hidrotermalizada. A ocorrência Barriguda situa-se no âmbito dos filitos onde o ouro é hospedado por veios de quartzo $\mathrm{N} 45^{\circ} \mathrm{E} /$ subvertical, enquanto que na ocorrência Santana o ouro ocorre 
em veios de quartzo de direções $\mathrm{N} 15^{\circ} \mathrm{E}, 50^{\circ} \mathrm{SE}$, e NS e $40^{\circ} \mathrm{E}$, encaixados em filito carbonoso, intercalado em granada xisto. Em ambas as ocorrências, os veios apresentam até $10 \mathrm{~cm}$ de espessura, bordejados por zonas estreitas de intensa sericitização. Em todas as ocorrências mencionadas, os veios apresentam-se geralmente fraturados, segmentados e budinados, e o quartzo dos veios é geralmente leitoso e localmente translúcido. Veios de quartzo com estrutura em pente são freqüentes, os quais foram preteridos pela atividade garimpeira. Os veios preenchem fraturas de alívio e, provavelmente, são posteriores aos veios de quartzo leitoso auríferos. Embora controladas por fraturas de diferentes direções, as ocorrências auríferas de São Domingos estão restritas a uma área estruturalmente caracterizada pela interseção de falhas de cisalhamento NW e NE.

O ouro foi observado apenas sob lupa binocular durante a preparação de amostras para determinações geocronológicas das rochas metavulcânicas, apresentando-se na forma de grãos de dimensões entre 150 e $300 \mathrm{~mm}$. O único sulfeto presente é a pirita, ocorrendo, muito raramente, em veios de quartzo no riolito, os quais contêm as maiores concentrações de ouro em São Domingos (Rendón 2002)

CASSITERITA As ocorrências de cassiterita, localizadas na Fazenda Cristal, aproximadamente $10 \mathrm{~km}$ a sul da cidade de São Domingos (Fig. 2), são hospedadas por veios de greisen, quartzo e, predominantemente, pegmatito, milonitizados e encaixados em xisto da SSD. Tais veios apresentam espessura máxima de $5 \mathrm{~m}$ e, até $250 \mathrm{~m}$ de extensão, boudinados e controlados por fratura $\mathrm{N} 70^{\circ}$ $80^{\circ} \mathrm{W} /$ subvertical, coincidente com a direção de falha de cisalhamento na região. O pegmatito é constituído de quartzo, oligoclásio, moscovita e, subordinadamente, apatita, turmalina e cassiterita. Os dois últimos ocorrem disseminados e, localmente em vênulas de quartzo. Nas bordas dos veios de pegmatito, o xisto foi submetido a turmalinização.

A cassiterita e a turmalina foram analisadas por microssonda eletrônica Cameca SX-50, no Instituto de Geociências da UnB, operada com $15 \mathrm{kV}$ e $25 \mathrm{nA}$, tempo de 10 s e tamanho do feixe de 10 $\mathrm{u}$. A turmalina ocorre como cristais prismáticos, com comprimento de até 0,02 a 2 mm, marrom esverdeados, sem zonação. Sua composição química, no diagrama $\mathrm{Ca}-\mathrm{Fe}-\mathrm{Mg}$ proposto por Hawthorme \& Henry (1997), corresponde à variedade schorlita. A cassiterita analisada ocorre em pegmatito, na forma de cristais de tonalidade marrom amarelado, de 1 a $5 \mathrm{~mm}$ de comprimento, com concentrações de 0,92 a 0,98 a.f.u. de Sn, 0,02 a 0,014 a.f.u. de Ta e 0,01 a 0,03 a.f.u. de $\mathrm{Nb}$ (Rendón 2002).

Correntina OURO Na região de Correntina, o ouro vem sendo explorado desde meados do século XVIII, quando então, aluviões e veios de quartzo foram lavrados por meio de garimpagem. A caracterização mais detalhada sobre as ocorrências de ouro da região de Correntina encontra-se indicada nos relatórios dos projetos Correntina (Andrade et al. 1981) e Serra da Extrema (Andrade et al. 1988), desenvolvidos pela Companhia Baiana de Pesquisa Mineral - CBPM. As ocorrências auríferas cadastradas e caracterizadas por esses dois projetos são as denominadas de Manga do Zó, Fazenda Manoel Mendes, Fazenda Tabuá, Fazenda Brejinho, Fazenda Córrego Barreiro, Fazenda Barreiro Vermelho, Serra da Extrema e Sete Ilhas. De um modo geral, grãos de ouro encontramse em vênulas e veios de quartzo de direção $\mathrm{N} 20^{\circ}-40^{\circ} \mathrm{E} /$ vertical, encaixados em monzodiorito e biotita granito do stock monzodioritico, xisto e filito da Formação Extrema e em xenólitos e intrusões de dimensões restritas contituídas de rocha básicaultrabásica. A principal ocorrência aurífera na região constitui a Mina São Rafael, situada no perímetro urbano de Correntina, a sul da cidade (Fig. 4). No âmbito da mina, ocorre um monzogranito contendo porções métricas de rocha gabróica-piroxenítica. $\mathrm{O}$ monzogranito é atravessado por vênulas e veios de quartzo retilínios, de $50 \mathrm{~cm}$ de espessura máxima, enquanto que a rocha gabróica-piroxenítica contém lentes e boudins de quartzo. Os veios de quartzo apresentam direção predominante para $\mathrm{N} 50^{\circ}-60^{\circ} \mathrm{E} /$ $80^{\circ} \mathrm{NW}$. O ouro dos veios de quartzo ocorre na forma de partículas de até $2 \mathrm{~mm}$ de dimensão, sendo que as concentrações mais elevadas de ouro foram obtidas no metapiroxenito $(0,26 \mathrm{ppm}$ a $5,6 \mathrm{ppm}$ $\mathrm{Au})$ e lentes de quartzo no mesmo (1,7 ppm Au), enquanto que o tonalito e veios de quartzo encaixados no mesmo são os menos auríferos, contendo 0,4 ppm Au e 0,16 ppm a 1,7 ppm Au, respectivamente. Concentrações de arsênio são inferiores a 20 ppm e sulfetos são totalmente ausentes. A atividade garimpeira geralmente concentra-se em veios de quartzo encaixados em tonalito, os quais são marginados por rocha escura, produto de alteração hidrotermal constituído por biotita e carbonato, subordinadamente quartzo, zircão e mineral opaco. Figueiredo et al. (1996) obtiveram, nos veios de quartzo encaixados no tonalito, concentrações de ouro com máximo de 38,89 ppm, média de 6,63 ppm.

\section{LITOGEOQUIIMICA DOS PRODUTOS DE ALTERAÇÃO} HIDROTERMAL A Tabela 3, apresenta as concentrações de elementos traço obtidas para as amostras analisadas e na figura 8 são mostrados os padrões de distribuição obtidos para os elementos traço dosados, normalizados a rocha inalterada. Os valores de $\mathrm{Sb}$ não foram incluidos nos diagramas por apresentarem, sempre, concentrações inferiores ao do limite de detecção do método analítico $(0.1 \mathrm{ppm})$. O padrão obtido para a alteração hidrotermal do tonalito da ocorrência Cemitério 1 mostra enriquecimento em Rb, Nb, Sn, Y, Cs, Bi, Cu, Pb, Zn, As e Au (Fig. 8a), enquanto que o riolito hidrotermalizado da ocorrência Padre, enriquecimento em Ba, Sn, Mo, W, Y, As e Au (Fig. 8a). A maioria dos elementos que mostra enriquecimento é compatível com rochas magmáticas ácidas, e portanto, é possível que o fluido hidrotermal tenha tido como fonte tais tipos de rochas, e/ou lixiviou aqueles elementos durante sua percolação no tonalito e no riolito. O padrão de distribuição obtido para o filito hidrotermalizado da ocorrência Barriguda revela enriquecimento em $\mathrm{Rb}, \mathrm{Sn}, \mathrm{W}, \mathrm{Y}, \mathrm{Cs}, \mathrm{Bi}, \mathrm{Cu}$, $\mathrm{Pb}, \mathrm{Zn}, \mathrm{Ni}$, As e $\mathrm{Au}$, o que sugere, também, a participação do tonalito e/ou riolito no processo hidrotermal, ou como fonte do fluido ou como contaminante do mesmo (Fig. 8a). O filito carbonoso com pirita abundante, aflorante no âmbito das ocorrências de ouro, mostra enriquecimento em praticamente todos os elementos traço dosados e, portanto, pode, também, ter contribuído para a compo-

Tabela 2 - Resultados de análises por difratometria de raios- $X$ em minerais hidrotermais de São Domingos.

\begin{tabular}{lcccc}
\hline \multicolumn{1}{c|}{ Ocorrência } & Próxima ao veio & Intermediária & Distante do veio \\
\hline Cemitério I & K, Q, I, G, M & K, Q, I, G, M & K, Q, I, G \\
Cemitério II & H. G K, Q, I. & H, G K, Q, I, & K, Q, I, H, G \\
Padre & G K, Q, I & G K, Q, I, & K, Q, I, G \\
Santana & G, K, Q, G & K, Q, G & \\
Barriguda & K, Q, Mo & K, Mo, Q & \\
\hline
\end{tabular}

$\mathrm{K}=$ caolinita, $\mathrm{Q}=$ Quartzo, $\mathrm{I}=\mathrm{Illita}, \mathrm{G}=$ Goetita, $\mathrm{M}=$ Montmorillonita, $\mathrm{H}=$ Hematita $\mathrm{Mo}=$ Moscovita 
sição química do fluido hidrotermal. O carbonato-biotita xisto que bordeja veios de quartzo na mina São Rafael, Correntina, apresenta, em relação ao monzogranito, enriquecimento em $\mathrm{Rb}, \mathrm{Sn}, \mathrm{Cs}, \mathrm{Zn}$,

Tabela 3 - Concentrações de elementos traço (ppm) em rochas produtos de alteração hidrotermal em São Domingos e Correntina. (*) concentrações expressas em ppb.

\begin{tabular}{|c|c|c|c|c|c|c|}
\hline \multirow{3}{*}{\begin{tabular}{c|} 
Àrea \\
ocorrência \\
Amostra \\
\end{tabular}} & \multirow{2}{*}{\multicolumn{4}{|c|}{$\begin{array}{c}\text { SSD } \\
\text { Padre }\end{array}$}} & \multirow{2}{*}{\multicolumn{2}{|c|}{$\begin{array}{c}\text { SCO } \\
\text { São Rafael }\end{array}$}} \\
\hline & & & & & & \\
\hline & CR-71 & CR-82 & CR-F1 & CR-6C & CR-216 & CR-202 \\
\hline rocha & riodacito & alteração & alteração & alteração & mzgranito & biotitito \\
\hline $\mathbf{B a}$ & 664,00 & 446,30 & 1636,00 & 339,50 & 995,00 & 306,20 \\
\hline $\mathrm{Sr}$ & 122,10 & 126,80 & 58,40 & 118,60 & 248 & 138,90 \\
\hline $\mathbf{R b}$ & 162,10 & 41,70 & 180,80 & 47,90 & 132 & 405,60 \\
\hline Nb & 13,20 & 8,80 & 11,00 & 8,20 & 10,3 & 12,10 \\
\hline Sn & 6,00 & 2,00 & 8,00 & 6,00 & 2 & 5,00 \\
\hline Mo & 0,80 & 0,40 & 0,30 & 1,00 & 1,3 & $<0.1$ \\
\hline $\mathbf{Y}$ & 26,50 & 64,60 & 36,40 & 62,80 & 19 & 17,30 \\
\hline Cs & 14,80 & 1,80 & 5,20 & 2,60 & 4,8 & 25,90 \\
\hline $\mathbf{B i}$ & 0,90 & 0,10 & 1,00 & 0,10 & 0,1 & $<0.1$ \\
\hline $\mathrm{Cu}$ & 35,00 & 7,26 & 16,50 & 10,60 & 13,68 & 1,80 \\
\hline $\mathbf{P b}$ & 13,00 & 6,10 & 10,90 & 10,70 & 10 & 1,20 \\
\hline Zn & 114,00 & 102,00 & 48,00 & 82,00 & 37 & 167,00 \\
\hline $\mathrm{Ni}$ & 48,50 & 1,40 & 21,10 & 1,50 & 7 & 182,40 \\
\hline As & 4,10 & 2,70 & 5,40 & 8,50 & 1,3 & 2,10 \\
\hline $\mathbf{A u}(*)$ & 3,70 & 58,60 & 4,10 & 1312,00 & 0,6 & 17,40 \\
\hline Cd & 0,20 & 0,10 & $<0.1$ & $<0.1$ & $<.1$ & 0,10 \\
\hline Sb & $<0.1$ & $<.1$ & 0,10 & $<0.1$ & 0,1 & $<0.1$ \\
\hline Ag & $<0.1$ & $<.1$ & $<0.1$ & 0,10 & 0,1 & $<0.1$ \\
\hline $\mathrm{Hg}$ & $<.01$ & 0,10 & 0,01 & 0,01 & 0 & 0,01 \\
\hline $\mathbf{U}^{\circ}$ & 4,60 & 1,30 & 2,60 & 1,50 & 3,8 & 1,60 \\
\hline
\end{tabular}

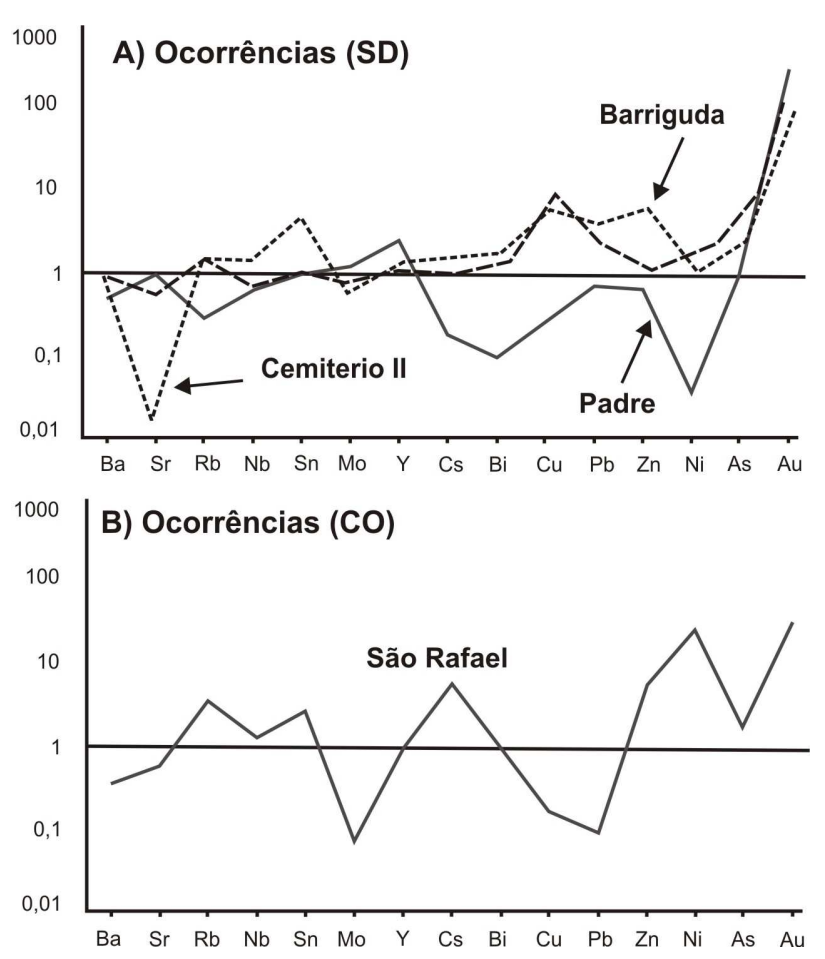

Figura 8 - Diagramas multielementares em rochas produtos da alteração hidrotermal das ocorrências de São Domingos (SD) e Correntina (CO): (A) ocorrências Cemitério, Padre e Barriguda, normalizadas a tonalito, riolito e filito inalterados, respectivamente; (B) mina São Rafael, normalização a monzogranito.
As e $\mathrm{Au}$, sugerindo protolito granitóide. No entanto, o acentuado enriquecimento em Ni sugere protolito básico-ultrabásico, ou que o fluido percolou tal tipo de rocha (Fig. 8b).

INCLUSÔES FLUIDAS O estudo em inclusões fluidas foi realizado em amostras de veios de quartzo coletadas nas ocorrências Cemitério I e Cemitério II (Fig. 2), tendo sido confeccionadas 7 lâminas bipolidas, porém, somente três delas apresentaram-se com tonalidade clara e transparentes. A preparação das amostras foi efetuada de acordo com as recomendações de Shepherd et al. (1985). Após a identificação dos tipos de inclusões, procedeu-se estudo microtermométrico, utilizando-se platina de resfriamento e aquecimento, LINKAM ,THM 600, TMS 93, com um sistema de bomba de nitrogênio LNP 2, modelo MTM 85, que permite atingir temperaturas de $-180^{\circ} \mathrm{Ca}+600^{\circ} \mathrm{C}$, com reprodutibilidade de $0,1^{\circ} \mathrm{C}$, entre $-60^{\circ} \mathrm{C} \mathrm{e}+400^{\circ} \mathrm{C}$. Este sistema está acoplado a um console de leitura e monitoriamento de temperatura e a um microscópio Olimpus com objetivas de 10x, 25x, 50x e 80x, o que permitiu análises de inclusões fluidas inferiores a $10 \mu \mathrm{m}$. Os cálculos de salinidade, densidade e pressão foram feitos utilizando-se programa Macflincor.

O estudo permitiu identificar tres populações de inclusões, ou seja, duas bifásicas e uma trifásicas, sendo que as bifásicas apresentam-se como aquosas, tipo 1 presentes nos planos de crescimento do cristal ou em trilhas (secundárias) e tipo 2 associadas sempre a microfracturas (pseudo-secundárias), e as trifásicas, como aquo-carbônicas primárias tipo 3, diferenciadas, ao microscópio, por conterem uma bolha de cor preta (30\% da inclusão). Embora o volume de gás (VG) nas bifásicas seja muito menor, tais inclusões são as mais abundantes (65\%), porém, suas dimensões reduzidas dificultaram sua caracterização. As inclusões aquosas secundárias correspondem a $40 \%$ das inclusões estudadas e se caracterizam por serem subarredondadas a irregulares, com cristal negativo e um VG menor a $15 \%$, enquanto que as inclusões aquocarbônicas são sub-arredondadas a irregulares, com cristal negativo e um VG entre $20 \%$ e $40 \%$.

Em Correntina, estudo das inclusões fluidas foi realizado em amostras de veios de quartzo com ouro coletadas nas ocorrências São Rafael (Fig. 4).O quartzo é opaco e com microfracturas. Para tanto, foram confeccionadas 5 lâminas bipolidas, porém, somente em três delas, devido a sua transparência, foi possível realizar algum tipo de estudo. Identificaram-se dois tipos de inclusões: primárias, possivelmente aquocarbônicas, e secundárias, aquosas e aquocarbônicas. As dimensões bastante reduzidas destas inclusões impossibilitaram efetuar microtermometria.

Microtermometria Os resultados microtermométricos (Tabela 4) obtidos para amostras de quartzo de veio das ocorrências Cemitério I e Cemitério II permitiram identificar dois sistemas de fluidos: aquosos $\left(\mathrm{H}_{2} \mathrm{O}-\mathrm{NaCl}\right)$ e aquocarbônicos $\left(\mathrm{H}_{2} \mathrm{O}-\mathrm{NaCl}-\mathrm{CO}_{2}\right)$. Um total de 49 inclusões aquocarbônicas tipo 3 foram estudadas, submetendo-as a resfriamento e aquecimento. A fusão do $\mathrm{CO}_{2}$ foi observada em todas as inclusões, sendo que a mudança de fase ocorreu a temperaturas entre $-57,9^{\circ} \mathrm{Ce}-58,3^{\circ} \mathrm{C}$, com maior concentração em $-58,1^{\circ} \mathrm{C}$. A temperatura de fusão do clatrato ocorreu entre $9,4^{\circ} \mathrm{C}$ e $10^{\circ} \mathrm{C}$, com maior concentração em $9,8^{\circ} \mathrm{C}$. Segundo Shepherd et al.(1985), as inclusões constituidas exclusivamente de $\mathrm{CO}_{2}$ apresentam temperatura de fusão de clatrato em torno de $10^{\circ} \mathrm{C}$. A temperatura de homogeneização do $\mathrm{CO}_{2}$ apresentou valores entre $22,1^{\circ} \mathrm{Ce} 22,8^{\circ} \mathrm{C}$, com maior concentraçã̃o entre $22,2^{\circ} \mathrm{C} \mathrm{e} 22,4^{\circ} \mathrm{C}$, sendo que todas as bolhas homogeneizaram para a fase líquida. Esta 
Tabela 4-Resultados microtermométricos de inclusões fluidas em veios de quartzo aurífero de São Domingos

\begin{tabular}{|c|c|c|c|c|c|}
\hline Sistema & Teutético & Tf gelo & Wt\% NaCl & \multicolumn{2}{|c|}{ Densidade } \\
\hline $\mathrm{H}_{2} \mathrm{O}-\mathrm{NaCl}$ & $-20,8 \mathrm{a}-21,3$ & $-1,1 \mathrm{a}-0,2$ & $0,33 \mathrm{a} 1,86$ & \multicolumn{2}{|c|}{$0,69 \mathrm{a} 0,91$} \\
\hline \multicolumn{5}{|l}{} \\
\hline Sistema & $\mathrm{TfCO}_{2}$ & Tf clatrato & $\mathrm{Th} \mathrm{CO}_{2}$ & $\mathrm{Wt} \% \mathrm{NaCl}$ & Densidade \\
\hline $\mathrm{H}_{2} \mathrm{O}-\mathrm{CO}_{2}-\mathrm{NaCl}$ & $-58,7 \mathrm{a}-57,6$ & $9,4 \mathrm{a} 10$ & $22,1 \mathrm{a} 22,8$ & $0,02 \mathrm{a} 0,22$ & $0,89 \mathrm{a} 0,95$ \\
\hline
\end{tabular}

pequena variação na temperatura de homogeneização do $\mathrm{CO}_{2}$ é conseqüência, provavelmente, dos diferentes valores obtidos para VG. Temperatura de homogeneização total, salinidade e densidade, permitem obter informações importantes sobre as condições de pressão e temperatura em que os fluidos foram aprisionados. $\mathrm{Na}$ falta de outros indicadores, os valores de Th podem ser considerados como as temperaturas mínimas de aprisionamento do fluido. Durante o aquecimento, todas as inclusões aquo-carbônicas apresentaram temperatura de crepitação entre $290^{\circ} \mathrm{C}$ e $305^{\circ} \mathrm{C}$, sugerindo alta pressão de fluidos durante o aprisionamento das inclusões. A salinidade varia de 0,021 a $1,22 \%$ em peso de $\mathrm{NaCl}$ e a densidade entre 0,89 a 0,95 (Rendón 2002).

Nas 48 inclusões do sistema aquoso a temperatura do eutético foi de $-20,8^{\circ} \mathrm{C}$ a $21,3^{\circ} \mathrm{C}$, com moda em $21,1^{\circ} \mathrm{C}$. A temperatura de fusão do gelo (TfG) mostrou pouca variação de valores, com medidas entre $-1^{\circ} \mathrm{Ce}-0,2^{\circ} \mathrm{C}$, moda em $-0.5^{\circ} \mathrm{Ca}-0.9^{\circ} \mathrm{C}$. Os valores de salinidade de $\%$ em peso de $\mathrm{NaCl}$ ficaram entre $0,33 \%$ e $1,82 \%$ e densidade com valores entre 0,69 a 0,91 (Rendón 2002). Nas inclusões localizadas próximas às fraturas tipo 2 (aquosas pseudosecundárias), a temperatura de homogeneização foi de, aproximadamente $170^{\circ} \mathrm{C}$, enquanto que as outras crepitaram a $300^{\circ} \mathrm{C}$, da mesma forma que as aquocarbônicas.

No presente estudo, não foi observada, a olho nú, a presença de ouro no quartzo dos veios das ocorrências Cemitério 1 e Cemitério II. No entanto, o fato de terem sido lavrados por atividade garimpeira, e existir ouro em concentrados de bateia no local justificam considerar que tais veios são auríferos. Considerando-se que, provavelmente, as inclusões tipos 1,2 e 3 não são cogenéticas e que não foram identificadas inclusões de condições de temperatura e pressão mais elevadas que a do tipo 3, sugere-se que este último represente o fluido responsável pelas ocorrências de ouro em São Domingos. As inclusões tipos 1 e 2, as quais não coexistem com as inclusões aquocarbônicas, representam fluidos que, possivelmente, não teriam participado diretamente da gênese da mineralização. As características geológicas das ocorrências de ouro e as propriedades físico-quimicas das inclusões fluidas são compatíveis com fluido mineralizador de origem metamórfica.

CONCLUSÕES As seqüências vulcano-sedimentares e plutônicas associadas, presentes nas janelas erosivas de São Domingos e Correntina, apresentam características geológicas bastante semelhantes entre si, tendo sido depositadas no Paleoproterozóico, em ambiente de arco de ilha. A provável seqüência estratigráfica das rochas supracrustais, exposta mais completamente na região de São Domingos, compreende, da base para o topo, anfibolito e anfibólio xisto, filito e filito carbonoso com intercalações de metachert e riolito-riodacito, metagrauvaca com fragmentos de filito carbonoso e riolito-riodacito, e moscovita xisto.

Em contraste com as rochas granitóides anorogênicas intracontinentais da região de Monte Alegre de Goiás, a oeste de São Domingos (Botelho 1992, Pereira 2001), os granitóides de São Domingos e Correntina são cálcio-alcalinos e apresentam afinidade química com granitóides de arco vulcânico e sincolisionais. Estas características são as mesmas que Cruz e Kuyumjiam (1993) e Thomsen \& Kuyumjian (1994) evidenciaram para os granitóides paleoproterozóicos do Terreno Almas-Dianópolis (TO) localizado a norte da região de São Domingos.

Sugere-se que as rochas supracrustais e plutônicas associadas, presentes nas regiões de Almas-Dianópolis-Conceição do Tocantins (TO), São Domingos (GO) e Correntina (BA), sejam testemunhos de um arco magmático paleoproterozóico na borda ocidental do Cráton São Francisco. Considerando-se que o embasamento gnáissico-migmatítico (arqueano?) e as supracrustais com plutônicas associadas, paleoproterozóicos, das regiões de São Domingos e Correntina, são parcialmente cobertos por rochas sedimentares carbonáticas neoproterozóicas não deformadas do Grupo Bambuí e uma seqüência de arenitos cretácicos, horizontalmente estratificados, do Grupo Urucuia, conclui-se que a fase de deformação imposta ao embasamento e supracrustais com plutônicas associadas ocorreu anteriormente à deposição das rochas do Grupo Bambuí, durante o Evento Transamazônico. A potencialidade da região de São Domingos para depósitos minerais é estabelecida pela presença de várias ocorrências de ouro em veios de quartzo encaixados em filito e tonalito, e de cassiterita em veios de pegmatito, greisen e quartzo, encaixados em filitos. Em Correntina, o ouro ocorre, também, em veios de quartzo, encaixados em granodiorito-tonalito da Formação Correntina e seus xenólitos de metapiroxenito e metagabro. As características geológicas das ocorrências auríferas enfocadas em São Domingos e Correntina e as propriedades físico-químicas dos fluidos mineralizadores em São Domingos, tais como, fluidos aquocarbônicos, baixa salinidade, temperatura $>300^{\circ} \mathrm{C}$, pressão $>2 \mathrm{~Kb}$ e, em Correntina, fluidos aquocarbônicos, indicam uma origem metamórfica para os mesmos. Nas duas regiões, tais fluidos percolaram fraturas possivelmente transamazônicas, em condições correspondentes ao fácies xisto verde, promovendo, em São Domingos, sericitização e caolinização em tonalitos e filitos, e cloritização e carbonatização em riolito, nas ocorrências de ouro, e geração de pegmatito, greisen e quartzo, com turmalinização, nas de cassiterita. A presença de caolinita e illita na zona de alteração hidrotermal que bordeja os veios de quartzo das ocorrências de ouro sugerem diminuição da temperatura do fluido quando da interação com a rocha encaixante. A composição química das rochas hidrotermalizadas de São Domingos indica que o tonalito e o riolito, bem como o filito carbonoso com pirita, contribuíram, por meio de lixiviação, para a composição química do fluido mineralizador. Em Correntina, a alteração hidrotermal (biotitização) foi acompanhada de enriquecimento em $\mathrm{Rb}, \mathrm{Sn}, \mathrm{Cs}, \mathrm{Zn}, \mathrm{Ni}, \mathrm{As}$ e $\mathrm{Au}$, sugerindo que o fluido percolou tonalito e, devido a elevada concentração de Ni, rocha básica-ultrabásica. Os depósitos de ouro do Paiol e Vira-Saia (Cruz e Kuyumjian 1999; Cruz 2001), na região de Almas-Dianópolis, e as ocorrências de ouro de São Domingos e Correntina, atestam excelente potencialidade do arco magmático paleoproterozóico para mineralizações do tipo orogenic gold deposits decritos por Groves et al. 1998.

Agradecimentos Este artigo é parte da Dissertação do primeiro autor, concluída em 2002 no Instituto de Geociências da UnB, com apoio financeiro da CAPES na forma de bolsa de Mestrado. Os autores agradecem aos professores doutores José Oswaldo de 
Araújo Filho, Elton Luiz Dantas e Márcia Abrahão Moura pelas contribuições na obtenção e interpretação de dados de geologia estrutural, geocronologia e inclusões fluidas, respectivamente. Ao trabalho e à paciência dos revisores anônimos da RBG.

\section{Referências}

Alvarenga C. J. S. \& Silva J. R. C. 1975. Geologia de uma parte do municipio de Galheiros - GO. Relatório de Graduação, Instituto de Geociências, Universidade de Brasília, 105p.

Andrade A.R.F.. Siqueira, A.P., Fróes, R.J.B. 1981. Projeto Correntina. Salvador: CBPM. $4 \mathrm{v}$.

Andrade A.R.F. de, Cequeira Lopes G.A., Toledo L.A.A. de, Fróes R.J.R. 1988. Projeto Serra da Extrema. CBPM, Salvador, 2v.

Azevedo H.C.A., Mascarenhas J.F., Salomão J.B. 1979. Reconhecimento realizado em Correntina-BA., SME/CBPM. Inédito.

Barbosa O., Baptista M.B., Dyer R.C., Braun, P.G., Cotta J.C. - 1969Geologia e inventario dos recursos Minerais do Projeto Brasília, Rio de Janeiro, DNPM/PROSPEC.

Botelho N.F. 1992. Les ensembles granitiques subalcalins à péralumineux minéralisés en Sn et In de la Sous-Province Paranã, Etat de Goias, Brésil. Tese de doutoramento Universidade Paris VI. 343p.

Cordani U.G., Inda H.A.V., Kawashita K. 1979. Embasamento do Grupo Bambuí na região de Correntina, bacia do São Francisco, Estado de Bahia. In. SBG, Núcleo Bahia, Simpósio sobre o craton do São Francisco e suas faixas marginais, Resumos.

Cruz E.L.C.C da, 2001. A gênese e o contexto tectônico da mina Córrego Paiol, Terreno Almas-Conceição: um depósito de ouro hospedado em anfibolito do embasamento da Faixa de Dobramentos Brasília. Tese de Doutoramento, Instituto de Geociências, Universidade de Brasília, 183p.

Cruz E. L. C. C. \& Kuyumjiam R. M. 1993. O embasamento da porção norte da Faixa Brasília na região de Almas-Dianópolis. (TO) e seu posicionamento geodinâmico durante o Brasiliano. In: SBG, Núcleo Bahia, II Simp. sobre o Craton do São Francisco. Anais, 302-304.

Cruz E.L.C.C da \& Kuyumjian R. M., 1999. Mineralizações auríferas filoneanas do terreno granito-greenstone do Tocantins. Rev. Bras. Geoc., 29:291-298

Dardenne M.A. 2000. The Brasilia Fold Belt. In: Cordani U.G., Milani E.J., Thomaz Filho A., Campos D.A. (Eds.). Tectonic Evolutions Of South America, Brasil 2000, $31^{\text {th }}$ Intern. Geol. Cong. Rio de Janeiro, pp. 231-263.

Dardenne M.A.\& Shobbenhaus, C. 2001. O cráton São Francisco. In Metalogênese do Brasil. Cap 2: 107-164

Faria A, Marini J. O, Winge M., Kuyumjian M. R., Figueredo N. A 1983, Geologia da região de São Domingos, In: SBG, Cong. Bras. Geol., 34. Anais 2, p. 861-874.

Figueredo A.N de., Pires A.C.B., Franco, A.H., Costa Junior C.N., FreitasSilva F.H. 1996. Nota preliminar sobre o deposito de ouro de Correntina-BA, XXXIX Cong. Brás. Geol. 3 Anais V3 BA. In: SBG, Bong.Bras.Geol., 39, Anais, p. 3.

Freitas-Silva F.H. 1997. Geology of the area of the hidroelectric power station of São Domingos II (UHE-SDII). Charlotte, N.C. Duke Engineering \& Services. Relatorio Técnico, inédito, 56p

Freitas-Silva F.H. \& Oliveira C.G. 1999. O arco magmático paleoproterozóico de São Domingos-GO. In SBG. Simp. Geol Centro-Oeste, 7 e Simp. Geol. de Minas Gerais, 10, Boletim p.4.

Gioia S.M.C.L. \& Pimentel M.M. 2000. The Sm-Nd Method in the
Geochronology Laboratory of the University of Brasília. In. Acad. Bras. Cienc., 72:219-245.

Groves D.I., R. J., Goldfarb R. J., Gebre-Mariam M., Hagemann S,G., Robert F. 1998. Orogenic gold deposits: A proposed classification in the context of their crustal distribution and relationship to other gold deposit types. Ore Geol. Rev., 13:7-27

Hasui Y. \& Almeida F.F. 1970. Geocronologia do centro-oeste brasileiro.In: SBG, Congr. Bras. Geol., 19, Goiânia Boletim, 1: 5-26

Hawthorne F.C., Henry D.J. 1997. Classification of the Minerals of the Tourmaline Group. Eur. J. Min., 11:201-215

Inda H.A.V. \& Barbosa J.F. 1978. Texto explicativo para o mapa geológico do Estado da Bahia, escala 1:1000000. Salvador, SMECOM.

Irvine T.N. \& Baragar W. R. A. 1971. A guide to chemical classification of the common volcanic rocks. Can. J. Earth Sciences, 8:523-548.

La Roche H. de, Leterrier J., Grandclaude P., Marchal M., 1980. Classification of vulcanic and plutonic rocks using R1 R2 diagram major-elements analyses and its relationships with current nomenclature. Chem. Geol, 29:183-210.

Manier P. D. \& Piccoli P. M. 1989, Tectonic discrimination of granitoids. Geol Soc. Amer. Bulletin, 101:635-643.

Mascarenhas J. F. \& Garcia T. W., 1989, Mapa Geocronológico do Estado da Bahia, 1/1.000.000. Texto explicativo, S.G.M - SME, Salvador-Bahia.

Moraes Filho J.C.R. 1997. Programa de levantamentos geológicos do Brasil. CORIBE . Folha SD.23-X-C-V. Estado da Bahia. CPRM.

Pearce J.A., Harris N.B.W., Tindle A.G. 1984. Trace element discrimination diagrams for the tectonic interpretation of granitic rocks. J. Petrol., 25:956-983

Pearce J.A. 1996. Sources and Settings of Granitic rocks. Episodes, 19:120125

Pereira B. A. de, 2001. Caracterização dos Granitos e Pegmatitos Peraluminosos, Mineralizados em Sn-Ta, Monte Alegre de Goiás. Dissertação de Mestrado, Instituto de Geociências, Universidade de Brasília, 57p.

Pimentel M.M., Fuck R.A., Jost H., Ferreira Filho C.F., Araújo S.M., 2000. The basament of the Brasília fold belt and the Goías Magmatic Arc. In: U.G. Cordani E.J., Milani A., Thomaz Filho D.A., Campos (ed.) Tectonic Evolution of South America, Cong. Intern. Geol., 31, Rio de Janeiro, 195-230.

Pimentel M.M., Dardenne R.A., Fuck M.G., Viana S.L., Junges D.P., Fischel H.J., Seer E.L., Dantas E. 2001. Nd Isotopes and the provenance of detrital sediments of the Neoproterozoic brasília belt, central Brazil. J. S. Amer. Earth Scien. 14:571-585.

Rendón C. A. 2002. Ambiente geotectônico, geocronologia e mineralizações de ouro nas janelas erosivas de São Domingos (GO) e Correntina (BA). Dissertação de Mestrado, Inst. de Geociências, Universidade de Brasilia, Brasília, 81p.

Richard P., Shimizu N., \& Allègre C. J.1976. 143Nd/146Nd a natural tracer: an aplication to oceanic basalts. Earth Plan Sci. Lett, 31:269278. 
Mineralizações de ouro do tipo orogênico em arco magmático paleoproterozóico, borda oeste do Craton São Francisco, regiões de São Domingos (GO) e Correntina (BA).

Shapherd T.J, Ranking A.H., Alderton D.H.M. 1985. A pratical guide to fluid inclusion studies. New York :Blackie, 238p.

Sato K 1998, Evolução crustal da plataforma Sul Americana, com base na geoquímica isotópica Sm-Nd. Tese de Doutoramento, Instituto de Geociências, Universidade de São Paulo, 250p.

Texeira A N., Poli C. J and pn, Barbosa F. M. 1982. Contribuição à geologia e petrologia da região de São Domingos. In: SBG, Congr. Bras. Geol., 12, São Paulo, Anais pp.562-571
Thomsen F.P.R. \& Kuyumjian R.M. 1994. As formações ferriferas bandadas da região de Conceição de Tocantins -TO: caraterização preliminar. In: SBG, Congr. Brás. Geol, 38, Balneário Camboriú, Anais , pp.72-73.

Manuscrito A 1433

Recebido em 12 de junho de 2003 Revisão dos autores em 24 de maio de 2005

Revisão aceita em 05 de junho de 2005 